\title{
The impact of social organizations on HIV/AIDS prevention knowledge among migrants in Hefei, China
}

\author{
Wenting Wang ${ }^{1,2}$, Ren Chen ${ }^{1}$, Ying Ma ${ }^{1}$, Xuehui Sun ${ }^{1}$, Xia Qin ${ }^{1}$ and Zhi Hu*
}

\begin{abstract}
Background: There is a growing recognition of the need to provide HIV/AIDS prevention and care to migrant workers. Social involvement, a type of social capital, is considered a 'critical enabler' of effective HIV/AIDS prevention. Designated participation in formal community groups by the government (e.g., political parties) and informal, voluntary local networks by NGOs (e.g., alumni association, cultural \& sports club) play different roles in HIV prevention. The objective of this study is to assess the impact of different types of social organizations on HIV/ AIDS prevention knowledge among migrant workers.

Methods: A cross-sectional study of 758 migrants was conducted in Hefei, Anhui Province, China. Data were collected through a self-reported questionnaire. Logistic regression was used to assess associations between different social organizations and HIV/AIDS prevention.

Results: Migrants who participated in social organizations had a higher awareness of HIV/AIDS knowledge than migrants who do not participate in social organizations. Higher levels of HIV/AIDS knowledge is associated with positive HIV/AIDS behaviors for people who attended political parties (odds ratio [OR] = 3.49, 95\% Cl: 1.22-9.99). This effect is not significant for alumni association. For both political parties and alumni association members $(\mathrm{OR}=0.19,95 \% \mathrm{Cl}: 0.06-0.66, \mathrm{OR}=0.20,95 \% \mathrm{Cl}: 0.08-0.61$, respectively), people who exhibited higher levels of HIV/AIDS knowledge had more negative attitudes than those with less knowledge.
\end{abstract}

Conclusion: Social organizations play an important role in improving HIV/AIDS knowledge and behavior in migrants, providing a great opportunity for HIV/AIDS prevention.

Keywords: Migrants, Social organizations, HIV/AIDS, Political party, Alumni association

\section{Introduction}

The economy in China has developed rapidly over the past several years, and as a result there is an increase in the number of migrants as sources of social capital. Large-scale population migration has unique economic, social and demographic impacts, which may influence the risk of HIV transmission [1]. In China, there were an estimated 780,000 people living with HIV/AIDS (PLWHAs), and migrants accounted for $21.0 \%$ of PLWHAs [2]. Many factors including limiting familial and social network support, forcing migrants into

\footnotetext{
* Correspondence: 1203856674@qq.com

${ }^{1}$ School of Health Service Management, Anhui Medical University, No.81

Meishan Road, Hefei 230032, China

Full list of author information is available at the end of the article
}

physically demanding jobs and poor housing and living conditions limit migrants' access to health care and health information, which put migrants at higher risk of HIV infection [3]. Migrants are an important vector for the spread of HIV/AIDS. Participation in social organizations, a type of social capital, may provide an important channel to deliver information on safe sex practices and influence beliefs and attitudes towards Sexually Transmitted Infections (STI) prevention, including HIV/ AIDS. Leveraging social capital to improve HIV/AIDS prevention may be an important component to address this public health problem of high incidence and prevalence of HIV/AIDS in migrants [4].

Social capital is defined as the power, benefit, value emanating from any social interaction among 
individuals, groups, institution, communities or networks. It is the intrinsic and extrinsic benefit that members gain for belonging to a group or network. A type of social capital includes the number and types of social organizations. In China, social organizations include governmental organization like various political parties and non-governmental organization include alumni association and cultural \& sports clubs. According to 2013 statistics from China, the number of social organizations reached 289,026 , which is a $51.2 \%$ increase compared with 10 years ago [5]. Increases in social organization participation has played an important role in HIV/AIDS prevention and control and has gradually gained popularity in recent years [6, 7]. For instance, Bhattacharjee et al. investigated the role of membership in peer groups and found that community mobilization and peer group formation reduced HIV-related risk and vulnerability among female sex workers [8]. Campbell et al. explored pathways between community participation and HIV prevention, treatment and impact mitigation in Zimbabwe and found that community group membership is often associated with decreased HIV incedence, improved access to some services particularly amongst women [9]. FSWs who are exposed to social organizations are also at a substantially lower risk of STIs than those who are unexposed [10].

HIV/AIDS knowledge and attitudes towards HIV/AIDS and high-risk behaviors are the measures of the HIV/ AIDS prevention effect. The key question is if understanding whether the improvement of knowledge can change migrants' attitudes towards HIV/AIDS can reduce HIVrelated high-risk behaviors. Our previous study found that HIV/STI knowledge is related to attitude and practice for market vendors [11]. Malcolmet et al.' research showed knowledge alone is not sufficient to eliminate stigmatizing attitudes and behaviors [12, 13]. Lim et al.'s findings suggest that understanding HIV more broadly may be associated with lower HIV-related risk behavior and more comprehensive HIV knowledge may reduce HIV-related high-risk behavior [14].

In this paper, we aimed to explore the role of different types of social organizations on the prevention of HIV/AIDS among migrants. The difference on HIV/ AIDS knowledge levels between participants and nonparticipants for each organization were obtained. The impact of HIV/AIDS knowledge levels on attitudes towards HIV/AIDS and risk behavior was also analyzed for organizations with significant differences between two groups.

\section{Methods and materials}

\section{Ethical approval}

Informed consent is obtained from all the subjects before enrollment in the study. This study is prospectively performed and approved by the Biomedical Ethics Committee, Anhui Medical University with the following reference number: 20110238.

\section{Studying setting}

Anhui province is located in the southeast region of China with relatively low HIV/AIDS prevalence among Chinese provinces. This province has been selected for several reasons as follows: (1) Although with low prevalence, the morbidity showed an increasing trend in recent years. (2) More migrants can be found in Anhui province compared with other provinces with high prevalence. (3) Considering the feasibility, the reason to choose Anhui province is to guarantee the compliance of participates. As the provincial capital, Hefei is chosen for study site because many migrants have poured into this city in recent year. This study was conducted for 3 months from June to September in 2011. Based on the geographic distribution of migrants, we selected four representative areas in Hefei: construction sites, hotels, large markets and large enterprises.

\section{Study population and data collection}

This study examined a convenient selected sample, with the inclusion and exclusion criteria outlined below. To participate in our study, migrants needed to meet the following criteria: (1) $\geq 18$ years old; and (2) people who reside in this city for more than 6 months, but are not generally considered part of the official census count, which meaning that they did not have an official resident permit to live in Hefei. People who travel, study, visit friends and relatives, join the army are not included.

Trained investigators from the Anhui Medical University conducted face-to-face interviews with consented subjects, under the support of staff at the local Center for Disease Control and Prevention (CDC). Most of the data collection was undertaken either in the meeting rooms or other separate places which local CDC provided. With an overall response rate of $92.6 \%$, we conducted full interviews with a total of 758 participants.

\section{Measures \\ HIV/AIDS KAP survey}

The HIV/AIDS KAP survey included questions regarding HIV/AIDS knowledge and attitudes towards HIV/ AIDS and HIV-related high-risk behaviors. A total of 18 questions were asked including 8 questions concerning HIV/AIDS knowledge, 5 questions concerning HIV/ AIDS attitude and 5 questions concerning HIV/AIDS risk behaviors as illustrated in Fig. 1 shows. The right answers of knowledge, attitude and HIV/AIDS risk behavior are "No, No, No, Yes, Yes, Yes, Yes, Yes", "Yes, Yes, Yes, Yes, Yes" and "Yes, No, No, Yes, Yes", respectively. With the right answer, the participant's attitude 


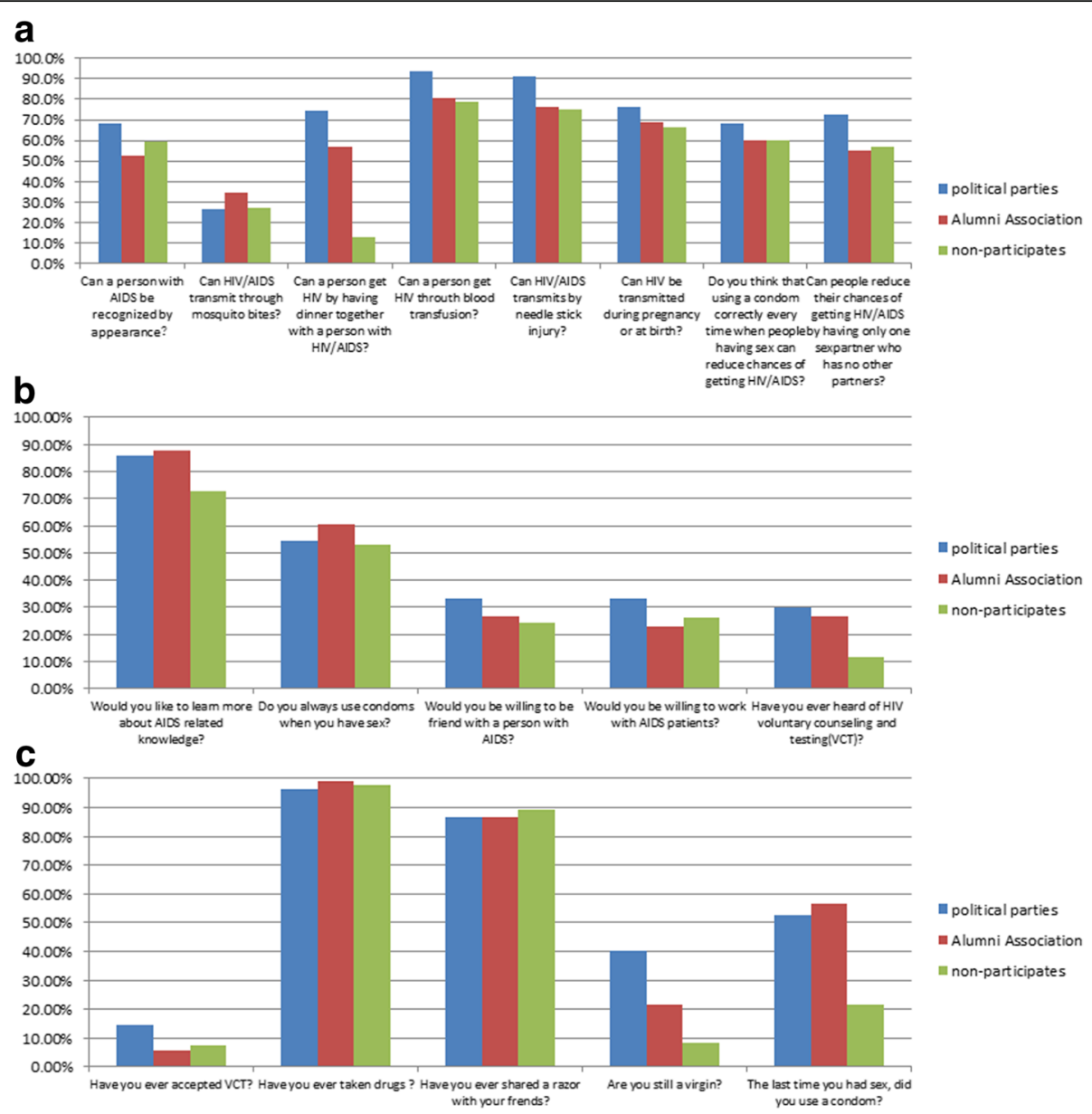

Fig. 1 The correct ratio of a 8 questions concerning HIV/AIDS knowledge, b 5 questions concerning HIV/AIDS attitude, and c 5 questions concerning HIV/AIDS risk behaviors among political parties, alumni association and non-participates

and behavior towards a problem are defined as positive attitude and positive behavior, respectively. The negative attitude include not willing to learn HIV/AIDS-related knowledge, not willing to use condom when having sex, discriminating against the HIV/AIDS patients, and not willing to know about VCT. And the positive behaviors include accepting VCT, keeping away from drugs, keeping good habits like not sharing razor, and avoiding high-risk sexual behavior like using condom. Each question was scaled with 3 points. A result recorded of ' 3 ' refers to a correct answer, a result of ' 2 ' refers to an unclear answer, and a result of ' 1 ' represents a wrong answer; $3=$ correct; $2=$ unclear; $1=$ wrong. Subjects with a behavior score of 1 point are defined as high risk behavior. All correct responses are summed, and those who had correct answers (3 points) of HIV/AIDS knowledge for more than 4 questions are considered having a high HIV/AIDS knowledge level. Those who had correct answers (3 points) of HIV/ AIDS attitudes and risk behaviors more than 2 questions respectively, were considered having high levels of HIV/ AIDS knowledge of attitudes and behaviors.

\section{Social support rating scale}

The SSRS is a dimension of social capital measured though a self-reported questionnaire, which has been used in our previous studies [15]. It has been proved highly reliable and valid among a wide range of Chinese populations including people who participate in the social organizations.

\section{Covariates}

The social demographic characteristics included age, marriage, education, hobby, and income. All these variables were categorized and listed in Table 1 . Social Organization was classified into 5 groups. Alumni association is defined as peer groups for schoolmates. Political parties included the Communist party and other political parties in Chinese mainland. Cultural \& sports clubs are for people with similar hobbies in cultural or sports activities. Other social organization refers to organizations with sample sizes less than 10 . 
Table 1 Social demographic characteristics of migrants, categories are mutually exclusive and exhaustive

\begin{tabular}{|c|c|c|}
\hline & $n$ & Percentage(\%) \\
\hline \multicolumn{3}{|l|}{ Gender } \\
\hline Male & 523 & 69.0 \\
\hline Female & 235 & 31.0 \\
\hline \multicolumn{3}{|l|}{ Age Group } \\
\hline $18-20$ & 72 & 9.5 \\
\hline $20-29$ & 307 & 40.5 \\
\hline $30-39$ & 169 & 22.3 \\
\hline$\geq 40$ & 210 & 27.7 \\
\hline \multicolumn{3}{|l|}{ Occupations } \\
\hline Catering industry workers & 134 & 17.7 \\
\hline Agricultural workers & 196 & 25.8 \\
\hline Enterprise workers & 209 & 27.6 \\
\hline Construction workers & 219 & 28.9 \\
\hline \multicolumn{3}{|l|}{ Income } \\
\hline$<1000$ & 209 & 27.6 \\
\hline $1000-2000$ & 344 & 45.4 \\
\hline$>2000$ & 205 & 27.0 \\
\hline \multicolumn{3}{|l|}{ Education } \\
\hline Some or completed primary education & 437 & 57.7 \\
\hline Secondary education & 232 & 30.6 \\
\hline Secondary education or higher & 89 & 11.7 \\
\hline \multicolumn{3}{|l|}{ Social Organization } \\
\hline Alumni association & 142 & 18.7 \\
\hline Political parties & 114 & 15.0 \\
\hline Cultural \& sports club & 41 & 5.4 \\
\hline Other social organizations & 312 & 41.2 \\
\hline Non-participates & 149 & 19.6 \\
\hline
\end{tabular}

\section{Statistical analysis}

All data is manually entered into Epidata 3.0 software by trained staff. In order to reduce error rate, the data entry was performed by two persons at the same time by cross-checked, and the verification was accomplished by other two persons who have data processing experience in our research group. Various statistical methods were utilized in the data analysis according to the distribution of the data. A descriptive analysis was performed on the sample, and the results were expressed as means and standard deviations (SDs), frequencies, and percentages. Chi-square tests were performed to assess whether there were significant differences in HIV-related knowledge between participants and non-participants. To test the potential association between HIV/AIDS knowledge and attitudes towards HIV/AIDS and risk behavior, univariate and multivariable logistic regression was employed to calculate crude and adjusted odds ratios (ORs) at the 95\% confidence interval (CI). The odds ratios are adjusted by knowledge levels about HIV/AIDS, gender, ages, occupation, individual income and education level. All statistical analysis is performed by SPSS 19.0 version and $P$ value $<0.05$ was taken as statistically significant.

\section{Results \\ Descriptive statistics}

Seven hundred fifty-eight samples are collected with response rate of $92.6 \%$ and the mean age of the respondents is 31.9 with a standard deviation of 10.7. The majority of migrants are men (69\%), who had a primary education or less (57.7\%), and had an individual monthly income below 2000 yuan $(\sim 300 \$)$. Among the migrants surveyed, 114 people participated in political parties, accounting for $15 \%$ of the total. One hundred forty-two people participated in alumni associations, accounting for $18.7 \%$ of the total. Forty-one migrants participated in various types of cultural and sports clubs, accounting for $5.4 \%$ of the total. A full descriptive summary of the respondents is provided in Table 1.

\section{Chi-square test}

HIV/AIDS knowledge, attitudes and HIV-related highrisk behaviors of migrants have been investigated and more details were shown in Fig. 1. According to the result, it is found that the majority of migrants are not willing to accept the HIV voluntary counseling testing.

Findings presented on Table 2 show that a majority (71.6\%) of political party members had more HIV/AIDS knowledge, while $68.4 \%$ of non-political party members had less HIV/AIDS knowledge. In addition, people who participated in alumni associations (76.8\%) had more HIV/AIDS knowledge than people who do not belong to the alumni association (67.9\%). We observed a statistically significant relationship between membership in political parties $\left(X^{2}=15.266, P\right.$-value $\left.<0.001\right)$ and alumni associations $\left(\chi^{2}=4.32, \mathrm{P}\right.$-value $\left.=0.043\right)$ with high $\mathrm{HIV} /$ AIDS knowledge.

\section{Logistic regression analysis Political parties}

In Table 3, the multinomial logistic regression showed that HIV/AIDS knowledge was significantly associated with attitudes towards HIV/AIDS $(\mathrm{OR}=0.19$, 95\% CI: 0.06-0.66). HIV/AIDS knowledge was significantly related to HIV-related high-risk behaviors $(\mathrm{OR}=3.49$, 95\% CI: 1.22-9.99), after adjustment for age, occupation, individual income and education level. Positive attitude towards HIV/AIDS in the high HIV/AIDS knowledge group was 0.194 times higher than that in 
Table 2 Distribution of participation in social organizations and AIDS knowledge score

\begin{tabular}{|c|c|c|c|c|c|c|}
\hline Social organizations & & Low knowledge & High knowledge & Total $n$ & $x^{2}$ & $p$-value \\
\hline \multirow[t]{3}{*}{ Political parties } & Participation & $21(28.4 \%)$ & $93(71.6 \%)$ & 114 & 9.20 & 0.002 \\
\hline & No participation & $210(31.6 \%)$ & $434(68.4 \%)$ & 644 & & \\
\hline & Total & $231(30.0 \%)$ & $527(70.0 \%)$ & 758 & & \\
\hline \multirow[t]{3}{*}{ Alumni association } & Participation & 33 (23.2\%) & 109 (76.8\%) & 142 & 4.32 & 0.043 \\
\hline & No participation & $198(32.1 \%)$ & $418(67.9 \%)$ & 616 & & \\
\hline & Total & $231(30.0 \%)$ & $527(70.0 \%)$ & 758 & & \\
\hline \multirow[t]{3}{*}{ Cultural \& sports club } & Participation & $7(17.0 \%)$ & 34 (83.0\%) & 41 & 3.67 & 0.057 \\
\hline & No participation & $224(31.2 \%)$ & $493(68.8 \%)$ & 717 & & \\
\hline & Total & $231(30.0 \%)$ & $527(70.0 \%)$ & 758 & & \\
\hline
\end{tabular}

lower knowledge group. HIV/AIDS knowledge group and positive behaviors in high HIV/AIDS knowledge group was 3.486 times higher than that in the less HIV/AIDS knowledge group. These results indicated that HIV/AIDS knowledge is positively correlated with positive behaviors and negatively correlated with attitudes towards HIV/AIDS. Education levels are also associated with attitudes towards HIV/AIDS (OR $=5$. 7, 95\% CI: 1.33-24.40). In addition, having a high income (family monthly income $>2000$ Yuan) $(\mathrm{OR}=4$. 895, 95\% CI: 1.18-20.37) and being agricultural workers $\quad(\mathrm{OR}=6.389, \quad 95 \% \quad \mathrm{CI}: \quad 1.03-39.62) \quad$ are

Table 3 Associations between AIDS knowledge and attitudes by political party

\begin{tabular}{|c|c|c|c|c|c|c|c|c|c|c|}
\hline \multirow[t]{2}{*}{ Variables } & & \multirow[t]{2}{*}{ Sample size } & \multicolumn{4}{|c|}{ High attitude score } & \multicolumn{4}{|c|}{ High behavior score } \\
\hline & & & $\mathrm{COR}^{\mathrm{a}}(95 \% \mathrm{Cl})$ & $P$ & $\mathrm{aOR}^{\mathrm{b}}(95 \% \mathrm{Cl})$ & $P$ & COR $(95 \% \mathrm{Cl})$ & $P$ & $\mathrm{aOR}(95 \% \mathrm{Cl})$ & $P$ \\
\hline \multirow{2}{*}{$\begin{array}{l}\text { Knowledge levels } \\
\text { about AIDS }\end{array}$} & Low & 21 & 1 & - & 1 & - & 1 & - & 1 & - \\
\hline & High & 93 & $0.25(0.09-0.71)$ & 0.009 & $0.19(0.058-0.66)$ & 0.007 & $2.90(1.06-7.84)$ & 0.037 & 3.49 (1.21-9.99) & 0.02 \\
\hline \multirow[t]{2}{*}{ Gender } & male & 90 & 1 & - & 1 & - & 1 & - & 1 & - \\
\hline & female & 24 & $0.854(0.34-2.12)$ & 0.734 & $0.943(0.29-3.04)$ & 0.922 & $0.26(0.10-0.69)$ & 0.007 & $0.475(0.14-1.57)$ & 0.224 \\
\hline \multirow[t]{4}{*}{ Ages } & $20<$ & 19 & 1 & - & 1 & - & 1 & - & 1 & - \\
\hline & $20-29$ & 70 & $1.01(0.29-3.9)$ & 0.987 & $0.69(0.08-5.75)$ & 0.733 & $1.80(0.50-6.46)$ & 0.367 & $0.67(0.07-5.85)$ & 0.719 \\
\hline & $30-39$ & 4 & $1.144(0.43-3.04)$ & 0.788 & $1.326(0.22-7.93)$ & 0.757 & $2.0(0.72-5.55)$ & 0.183 & $1.08(0.15-7.8)$ & 0.934 \\
\hline & $\geq 40$ & 21 & $2.73(0.24-30.66)$ & 0.416 & $2.05(0.11-38.31)$ & 0.631 & $0.68(0.58-7.6)$ & 0.744 & $3.03(0.17-54.39)$ & 0.452 \\
\hline \multirow[t]{4}{*}{ Occupation } & $\begin{array}{l}\text { Industry } \\
\text { worker }\end{array}$ & 29 & 1 & - & 1 & - & 1 & - & 1 & - \\
\hline & $\begin{array}{l}\text { Agricultural } \\
\text { worker }\end{array}$ & 4 & $1.42(0.50-3.96)$ & 0.507 & $3.19(0.57-17.62)$ & 0.183 & $8.94(2.7-29.41)$ & 0.000 & $6.39(1.03-39.62)$ & 0.046 \\
\hline & $\begin{array}{l}\text { Enterprise } \\
\text { workers }\end{array}$ & 51 & $3.00(0.28-32.09)$ & 0.364 & $2.32(0.14-38.40)$ & 0.555 & $0.78(0.07-8.52)$ & 0.837 & $0.50(0.04-7.70)$ & 0.605 \\
\hline & $\begin{array}{l}\text { Construction } \\
\text { workers }\end{array}$ & 30 & $1.22(0.49-3.00)$ & 0.67 & $2.68(0.55-13.07)$ & 0.224 & $1.39(0.53-3.63)$ & 0.508 & $1.13(0.21-6.01)$ & 0.883 \\
\hline \multirow[t]{3}{*}{ Individual income } & $1000<$ & 23 & 1 & - & 1 & - & 1 & - & 1 & - \\
\hline & $1000-2000$ & 69 & $1.91(0.56-6.46)$ & 0.301 & $1.96(0.44-8.66)$ & 0.374 & $2.89(0.74-11.37)$ & 0.128 & $2.98(0.55-15.99)$ & 0.204 \\
\hline & $>2000$ & 22 & $0.86(0.3-2.34)$ & 0.755 & $0.61(0.17-2.24)$ & 0.461 & $5.86(1.79-19.10)$ & 0.003 & $4.89(1.17-20.37)$ & 0.029 \\
\hline \multirow[t]{3}{*}{ Education level } & $\begin{array}{l}\text { Some or } \\
\text { completed } \\
\text { primary } \\
\text { education }\end{array}$ & 22 & 1 & - & 1 & - & 1 & - & 1 & - \\
\hline & $\begin{array}{l}\text { Secondary } \\
\text { education }\end{array}$ & 55 & $2.53(0.81-7.88)$ & 0.111 & $5.70(1.33-24.40)$ & 0.019 & $0.66(0.22-1.90)$ & 0.438 & $0.95(0.19-4.80)$ & 0.953 \\
\hline & $\begin{array}{l}\text { Above } \\
\text { secondary } \\
\text { education }\end{array}$ & 37 & $0.98(0.43-2.26)$ & 0.967 & $1.74(0.61-4.89)$ & 0.297 & $0.73(0.32-1.96)$ & 0.433 & $0.90(0.30-2.70)$ & 0.856 \\
\hline
\end{tabular}


Table 4 Associations between AIDS knowledge and attitudes by alumni association

\begin{tabular}{|c|c|c|c|c|c|c|c|c|c|c|}
\hline \multirow[t]{2}{*}{ Variables } & & \multirow[t]{2}{*}{ Sample size } & \multicolumn{4}{|c|}{ High attitude score } & \multicolumn{4}{|c|}{ High behavior score } \\
\hline & & & $\mathrm{COR}^{\mathrm{a}}(95 \% \mathrm{Cl})$ & $P$ & $\mathrm{aOR}{ }^{\mathrm{b}}(95 \% \mathrm{Cl})$ & $P$ & COR $(95 \% \mathrm{Cl})$ & $\mathrm{P}$ & aOR $(95 \% \mathrm{Cl})$ & $\mathrm{P}$ \\
\hline \multirow{2}{*}{$\begin{array}{l}\text { Knowledge levels } \\
\text { about AIDS }\end{array}$} & Low & 33 & 1 & - & 1 & - & 1 & - & 1 & - \\
\hline & High & 109 & $0.16(0.06-0.44)$ & 0.000 & $0.20(0.08-0.61)$ & 0.005 & $2.00(0.92-4.36)$ & 0.079 & $1.56(0.63-3.85)$ & 0.334 \\
\hline \multirow[t]{2}{*}{ Gender } & male & 92 & 1 & - & 1 & - & 1 & - & 1 & - \\
\hline & female & 40 & $1.913(0.87-4.22)$ & 0.109 & $0.317(0.21-1.67)$ & 0.586 & $0.764(0.36-1.62)$ & 0.483 & $1.06(0.41-2.80)$ & 0.905 \\
\hline \multirow[t]{4}{*}{ Ages } & $20<$ & 33 & 1 & - & 1 & - & 1 & - & 1 & - \\
\hline & $20-29$ & 79 & $3.23(0.34-31.07)$ & 0.306 & $4.25(0.33-55.15)$ & 0.268 & $5.31(0.56-50.53)$ & 0.146 & $2.20(0.18-24.36)$ & 0.547 \\
\hline & $30-39$ & 21 & $3.33(0.37-29.96)$ & 0.286 & $3.17(0.28-35.20)$ & 0.347 & $3.52(0.72-5.55)$ & 0.261 & $1.31(0.13-13.63)$ & 0.809 \\
\hline & $\geq 40$ & 9 & $5.63(0.53-58.90)$ & 0.15 & $5.73(0.45-72.33)$ & 0.177 & $1.53(0.13-17.33)$ & 0.727 & $1.22(0.09-15.25)$ & 0.877 \\
\hline \multirow[t]{4}{*}{ Occupations } & $\begin{array}{l}\text { Catering industry } \\
\text { worker }\end{array}$ & 40 & 1 & - & 1 & - & 1 & - & 1 & - \\
\hline & $\begin{array}{l}\text { Agricultural } \\
\text { worker }\end{array}$ & 17 & $0.28(0.09-0.80)$ & 0.018 & $0.35(0.57-17.62)$ & 0.111 & $8.80(2.71-28.53)$ & 0.000 & $7.81(2.05-29.77)$ & 0.003 \\
\hline & Enterprise workers & 54 & $0.41(0.10-1.67)$ & 0.215 & $0.39(0.08-1.95)$ & 0.252 & $1.32(0.23-6.63)$ & 0.732 & $1.88(0.33-10.50)$ & 0.475 \\
\hline & $\begin{array}{l}\text { Construction } \\
\text { workers }\end{array}$ & 31 & $0.93(0.36-2.35)$ & 0.876 & $1.17(0.54-13.07)$ & 0.792 & $2.53(0.82-7.78)$ & 0.105 & $2.73(0.21-6.01)$ & 0.124 \\
\hline \multirow{3}{*}{$\begin{array}{l}\text { Individual } \\
\text { income }\end{array}$} & $1000<$ & 39 & 1 & - & 1 & - & 1 & - & 1 & - \\
\hline & $1000-2000$ & 73 & $0.85(0.31-2.55)$ & 0.903 & $1.03(0.28-3.73)$ & 0.966 & $1.21(0.73-11.37)$ & 0.729 & $0.59(0.16-2.16)$ & 0.43 \\
\hline & $>2000$ & 30 & $0.28(0.24-1.50)$ & 0.599 & $0.75(0.25-2.24)$ & 0.61 & $1.75(0.67-4.57)$ & 0.251 & $1.09(0.37-3.18)$ & 0.87 \\
\hline \multirow[t]{3}{*}{ Education level } & $\begin{array}{l}\text { Some or completed } \\
\text { primary education }\end{array}$ & 38 & 1 & - & 1 & - & 1 & - & 1 & - \\
\hline & $\begin{array}{l}\text { secondary } \\
\text { education }\end{array}$ & 74 & $0.29(0.09-0.86)$ & 0.027 & $0.30(0.08-1.12)$ & 0.075 & $0.52(0.18-1.51)$ & 0.232 & $0.38(0.1-1.38)$ & 0.139 \\
\hline & $\begin{array}{l}\text { Above secondary } \\
\text { education }\end{array}$ & 30 & $0.66(0.43-2.26)$ & 0.319 & $0.48(0.15-1.51)$ & 0.213 & $0.66(0.27-1.62)$ & 0.364 & $0.58(0.18-1.81)$ & 0.347 \\
\hline
\end{tabular}

${ }^{\text {aCrude odds ratio }}$

${ }^{\mathrm{b}}$ Adjusted odds ratio

All items with $P<0.05$ were bold italics

significantly associated with an increasing odds of positive behaviors.

\section{Alumni association}

As shown in Table 4, the multivariate adjusted ORs indicated that high HIV/AIDS knowledge is significantly associated with a lower odds of positive attitudes towards HIV/AIDS (OR $=0.20,95 \%$ CI: 0.07-0.61). HIV/AIDS knowledge is not significantly related to positive HIVrelated behaviors. Those in the high HIV/AIDS knowledge group are less likely to have positive attitudes towards HIV/AIDS compared to those in the lower HIV/ AIDS knowledge group (OR: 0.20, 95\% CI: 0.08-0.61). In addition, being agricultural workers is significantly associated with an increased likelihood of positive behaviors $(\mathrm{OR}=7.82$, 95\%CI: 2.05-29.77).

\section{Discussion}

Our study provides an initial exploration of correlations between membership in social organizations and migrants' HIV/AIDS knowledge, attitudes and HIV-related high-risk behavior. With further development, our findings can be used to develop evidence-based policy to improve programs for HIV/AIDS prevention and control for migrant populations in China.

As can be seen, a relatively low proportion of migrants participated in social organizations. This phenomenon may due to the essence of migrants. Compared with the city's permanent population, the income of migrants is lower. They have to spend more time on work. Therefore, most migrants have no spare time to join the social organizations.

According to the results, migrants who are members of political parties or alumni associations have more HIV/AIDS knowledge than those who do not participate in any social organizations. Social organizations have promoted the advertisement of HIV/AIDS knowledge. In recent years, the government has paid more attention to social organizations so that HIV/AIDS-related knowledge can be spread more extensively among migrants, highlighting the need to take advantage of social organizations to carry out various training courses, which include HIV/AIDS prevention and knowledge. However, 
misconceptions about the routes of transmission are common. According to the answers by respondents, there are some false beliefs that HIV/AIDS can be transmitted by mosquito bites, a belief that has also been observed in previous studies [16]. To resolve this problem, social organizations should educate migrants on the routes of HIV/AIDS transmission and common fallacies about the virus.

The results of multiple logistic regression analysis demonstrate that HIV/AIDS knowledge is an important factor that influences political party members' behaviors and attitudes towards HIV/AIDS. High knowledge levels may have positive effects on people's behaviors. Research has shown that health education of HIV/AIDS can improve peoples' understanding of HIV/AIDS, thus it could decrease high-risk behaviors $[17,18]$. The impact of high knowledge level on HIV/AIDS-related behavior is not significant for migrants who participated in alumni associations. Different roles played by different social organizations may explain this phenomenon. Alumni associations or NGOs may have insufficient capacities, be deficient in resources, and not systematic enough compared with political parties to effectively reduce HIV/ AIDS-related behavior $[19,20]$. On the other hand, mobility of migrants causes difficulties for HIV/AIDS-related education and intervention services. Most of the migrants are from suburbs, and those who have lower HIV/AIDS-related knowledge than long-term residents are more likely to be engaged in high-risk behaviors [21]. Our previous research has shown that migrants are more likely to have high risk HIV-related sexual behavior than non-migrants [22]. Fang et al. mentioned that even if HIV/AIDS universal education improved knowledge levels that it will be hard to change their attitudes toward HIV/AIDS [23-25]. Most migrants have positive behaviors towards drug abuse regardless of social organization participation. In China, it is well known that taking drugs is harmful, requiring lots of money and with serious legal punishment, which makes people consciously regulate their own behaviors. On the one hand, humanistic care could be developed through community support and psychological care for migrants such as organizing some healthy, informative, interesting entertainment activities. With a rich amateur life, prostitution and drug abuse are obviously reduced while loneliness and dissatisfaction are also reduced and confidence is established in life. On the other hand, multichannel peer education and behavioral interventions could be carried out by social organizations. Health publicity and bulletin boards could be made and free condoms could be distributed in high HIV/AIDS epidemic areas. Social organizations with abundant resources could make in-depth publicity and face to face education for high-risk HIV populations.
There are still substantial intolerant attitudes towards HIV positive and HIV/AIDS patients. Interestingly, although migrants who participate in either political parties or alumni associations had higher-levels of HIV/ AIDS knowledge and are willing to obtain more HIVrelated knowledge. However, they also had more negative attitudes toward HIV/AIDS than migrants with lowlevels of HIV/AIDS knowledge, especially in the aspect of accepting HIV/AIDS patients. Other studies suggest that improving HIV/AIDS knowledge is not enough for to change attitudes. Yu et al.'s study which collected articles published between 1996 and 2006 concerning the effect of HIV/AIDS education intervention in migrants shows that health education for preventing HIV/AIDS is effective in changing attitudes in migrants [26]. However, Chen et al.'s study which is based on a sample of nurses in a single hospital in Jiamusi City, Heilongjiang, China, suggests the opposite conclusion. In their study, nurses who have a better understanding of HIV/AIDS prevention are more likely to have negative attitudes toward HIV/AIDS [27]. But study by Anahita Tavoosi also shows although the knowledge level seems to be moderately high, misconceptions about the routes of transmission are common among Iranian students [28]. So if we only disseminate preventive knowledge and promote a positive attitude, the results are likely to be unsatisfactory. The main reason for negative attitudes is that most of migrants have less education which affects their understanding and acceptance of HIV/AIDS knowledge. Better understanding of HIV/AIDS knowledge actually increased people's panic. They fear for their personal safety, their family members' health and others' attitudes towards them so that they want to stay away from this sensitive issue [27]. We also found that the majority of migrants are not willing to accept the HIV voluntary counseling testing (VCT). Two main factors led to this phenomenon. First, migrants cannot fully understand VCT. Second, social discrimination and stigma make people fear to seek and accept testing. Worrying about exposing their privacy is also a reason. This result shows that it is important for migrants to eliminate the misunderstanding so as to change their attitudes. Social organizations also should be more comprehensive when disseminating HIV/AIDS knowledge, not only to enhance the awareness of HIV/AIDS, but also to deepen the understanding of transmission and non-transmission routes to decrease panic and discrimination against HIV/AIDS. Social organizations can also take measures, including cooperating with local health sector, setting up VCT consulting point convenient to migrants, training VCT services consultant to improve the quality of their service, persisting in the principle of protecting consultants' privacy and perfecting care service after counseling and testing, to change migrants' attitude toward 
VCT and increase utilization of VCT in migrants. For migrants who have been infected with HIV/AIDS, it is applicable and effective for social organizations to take their advantages, which included training peer educators, developing civil relief, helping migrants infected with HIV/AIDS to engage in production to support themselves and providing psychological counseling for them, their participation can make services more professional, comprehensive and sustainable.

Here we observe a significant association between Agricultural workers and positive behavior $(P<0.05)$, but a wide range for $95 \%$ confidence interval. This phenomenon may due to the small sample size. Migrant who had higher incomes tended to exhibit more positive behaviors. People with higher incomes may have more educated social circles, which allows them receive more informative knowledge of HIV/AIDS [29-31].

Limitations of this study include the use of data from a cross-sectional survey, where causality cannot be ascertained. In addition, our sample size is not big enough due to limited funding. Finally, the results may not be generalized to all Chinese migrants. Our data is collected in Anhui province, which has a relatively low HIV/AIDS prevalence for China, and thus may not reflect the situation in other provinces due to regional differences in the epidemic characteristics of HIV/AIDS, prevention and control measures, funding, and policy environment.

\section{Conclusion}

Overall, community groups appear to raise awareness of HIV/AIDS-related knowledge. Therefore, increasing the percentage of migrants who are members of community groups could help increase HIV/AIDS knowledge. Although the knowledge is transferred into positive behavior, the two groups show different abilities. Due to excellent organization capacity, scale and the advantages in resources, the party organization could transfer knowledge into positive behavior better than alumni association as a government agency. It also indicates that organizations that target migrants specifically could have a much larger impact in HIV/AIDS knowledge on this relatively clandestine and high-risk population. As HIV/ AIDS knowledge publicity is not comprehensive, migrants with high knowledge on HIV/AIDS would have more negative attitudes towards HIV/AIDS than that with low-levels of HIV/AIDS knowledge. Although the current situation there is not complete, social organizations still play an important positive role on HIV/AIDS prevention for migrants. They present great potential in curbing the spread of HIV/AIDS. With the completing of organizational mechanism, social organizations will make a greater contribution to HIV/AIDS prevention for migrants in the future.

\section{Abbreviations}

Cl: Confidence interval; KAP: Knowledge, Attitude and Practice; NGOs: NonGovernment Organizations; OR: Odds ratio; VCT: Voluntary counseling testing

\section{Acknowledgments}

This research was supported by the National Natural Science Foundation of China (No. 71473002)

\section{Funding}

This research was funded the National Natural Science Foundation of China (No. 71473002) for data collection and analysis.

\section{Availability of data and materials}

The datasets used and/or analysed during the current study are available from the corresponding author on reasonable request.

\section{Authors' contributions}

WW participated in the data collection, performed the statistical analysis and manuscript write up. XS conceived of the study, and participated in data collection. RC, WW, YM, XQ and ZH participated in data interpretation and helped to draft the manuscript. All authors read and approved the final manuscript.

\section{Ethics approval and consent to participate}

Ethical approval for this study was obtained from the Biomedical Ethics Committee, Anhui Medical University. All subjects also gave informed consent for participation in the study.

\section{Competing interests}

The authors declare that they have no competing interests.

\section{Publisher's Note}

Springer Nature remains neutral with regard to jurisdictional claims in published maps and institutional affiliations.

\section{Author details}

'School of Health Service Management, Anhui Medical University, No.81 Meishan Road, Hefei 230032, China. ${ }^{2}$ Party Committee Office, Hangzhou First People's Hospital, No.261 Huansha Road, Hangzhou 310006, China.

Received: 13 June 2016 Accepted: 9 April 2018

Published online: 25 April 2018

\section{References}

1. Weine SM, Kashuba AB. Labor migration and HIV risk: a systematic review of the literature. AIDS Behav. 2012;16:1605-21.

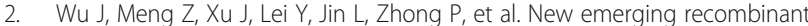
HIV-1 strains and close transmission linkage of HIV-1 strains in the Chinese MSM population indicate a new epidemic risk. PLoS One. 2013;8(1):e54322.

3. Tiruneh K, Wasie B, Gonzalez H. Sexual behavior and vulnerability to HIV infection among seasonal migrant laborers in Metema district, northwest Ethiopia: a cross-sectional study. BMC Public Health. 2015;15:1468.

4. Li H. Importance of prevention and control of AIDS among floating populations and relevant strategies. Chin J Health Educ. 2004;20:341-3.

5. National bureau of statistics of China. (2014). China Statistical Yearbook.

6. Gregson S, Terceira N, Mushati P, Nyamukapa C, Campbell C. Community group participation: can it help young women to avoid HIV? An exploratory study of social capital and school education in rural Zimbabwe. Soc Sci Med. 2004:58:2119-32.

7. Rimaz S, Nikooseresht Z, Vesali S, Nedjat S, Asadi-Lari M. A study on factors that drive variation in the levels of social capital among people living with HIV/AIDS in Iran. Global J Health Sci. 2015;7:351-7.

8. Bhattacharjee P, Prakash R, Pillai P, Isac S, Haranahalli M, Blanchard A, et al. Understanding the role of peer group membership in reducing HIV-related risk and vulnerability among female sex workers in Karnataka, India. AIDS Care. 2013;25:S46-54.

9. Campbell C, Scott K, Nhamo M, Nyamukapa C, Madanhire C, Skovdal M, et al. Social capital and HIV competent communities: the role of community groups in managing HIV/AIDS in rural Zimbabwe. AIDS Care. 2013;25:S114-22.

10. Yadav D, Ramanathan S, Goswami P, Ramakrishnan L, Saggurti N, Sen S, et al. Role of community group exposure in reducing sexually transmitted infectionrelated risk among female sex Workers in India. PLoS One. 2013;8:7. 
11. Hu Z, Wang DB, Liu HJ, Yang S, Ye DQ, Cao HT, et al. STD/AIDS knowledge, attitude, practice, and characteristics of market vendors in Hefei, China. AIDS Patient Care STDS. 2005;19:121-6.

12. Malcolm A, Agg LP, Bronfman M, Galvao J, Mane P, Verrall J. HIV-related stigmatization and discrimination: its forms and contexts. Crit Public Health. 1998:8:347-70.

13. Brown L, Macintyre K, Trujillo L. Interventions to reduce HIV/AIDS stigma: what have we learned? AIDS Educ Prev. 2003;15:49-69.

14. Lim TW, Davis WW, Quan VM, Frangakis C, Ha TV, Minh NL, et al. Association between hiv knowledge and risk behavior in persons who inject drugs in Thai Nguyen, Vietnam. Southeast Asian J Trop Med Public Health. 2014:45: 1425-36.

15. Chen R, Tao F, Ma Y, Zhong L, Qin X, Hu Z. Associations between social support and condom use among commercial sex workers in China: a crosssectional study. PLoS One. 2014:9(12):e113794.

16. Liu SY, Wang KL, Yao SP, Guo XT, Liu YC, Wang BY. Knowledge and risk behaviors related to HIV/AIDS, and their association with information resource among men who have sex with men in Heilongjiang province, China. BMC Public Health. 2010;10:9

17. Bazargan M, Kelly EM, Stein JA, Husaini BA, Bazargan SH. Correlates of HIV risk-taking behaviors among African-American college students: the effect of HIV knowledge, motivation, and behavioral skills. J Natl Med Assoc. 2000; 92:391-404.

18. Kirby DB, Laris BA, Rolleri LA. Sex and HIV education programs: their impact on sexual behaviors of young people throughout the world. J Adolesc Health. 2007:40:206-17.

19. Berkman A, Garcia J, Munoz-Laboy M, Paiva V, Parker R. A critical analysis of the Brazilian response to HIV/AIDS: lessons learned for controlling and mitigating the epidemic in developing countries. Am J Public Health. 2005; 95:1162-72.

20. Xu H, Zeng Y, Anderson AF. Chinese NGOs in action against HIV/AIDS. Cell Res. 2005;15:914-8.

21. Cai Y, Shi R, Shen TA, Pei B, Jiang XQ, Ye XX, et al. A study of HIV/AIDS related knowledge, attitude and behaviors among female sex workers in Shanghai China. BMC Public Health. 2010;10:7.

22. Hu Z, Liu H, Li X, Stanton B, Chen X. HIV-related sexual behavior among migrants and non-migrants in a rural area of China: role of rural-to-urban migration. BMC Public Health. 2006;120:339-45.

23. Fang $\mathrm{QY}$, Wu Q, Peng QL. The epidemiological factors and intervention strategies of AIDS in floating population. Chinese Med Rec. 2011;12:71-3.

24. Gordon-Larsen P. Obesity-related knowledge, attitudes, and behaviors in obese and non-obese urban Philadelphia female adolescents. Obes Res. 2001;9:112-8.

25. Jones $\mathrm{DH}$, Harel $\mathrm{Y}$, Levinson RM. Living arrangements, knowledge of health risks, and stress as determinants of health-risk behavior among college students. J Am Coll Health. 1992:41:43-8.

26. Yu C, Sun YH, Sun L, Wang B, Cao HY. Meta-analysis of effect on HIV/AIDS intervention in floating population. Chin J Evid Based Med. 2008:8:322-7.

27. Chen WT, Han M, Holzemer WL. Nurses' knowledge, attitudes, and practice related to HIV transmission in northeastern China. AIDS Patient Care STDS. 2004;18:417-22.

28. Tavoosi A, Zaferani A, Enzevaei A, Tajik P, Ahmadinezhad Z. Knowledge and attitude towards HIV/AIDS among Iranian students. BMC Public Health. 2004;4:6.

29. Altschuler J, Rhee S. Relationship power, sexual decision making, and HIV risk among midlife and older women. J Women Aging. 2015;27:290-308.

30. Calderon $C T$, Urizar DG, Blazquez CG, Ferreras BA, Rubio OR, Montrull FB, et al. Knowledge, attitudes and practices on HIV/AIDS and prevalence of HIV in the general population of Sucre, Bolivia. Braz J Infect Dis. 2015:19:369-75.

31. Kiderlen TR, Conteh M, Roll S, Seeling S, Weinmann S. Cross-sectional study assessing HIV-related knowledge, attitudes and behavior in the Namibian truck transport sector: readjusting HIV prevention programs in the workplace. J Infect Public Health. 2015;8:346-54.

\section{Ready to submit your research? Choose BMC and benefit from:}

- fast, convenient online submission

- thorough peer review by experienced researchers in your field

- rapid publication on acceptance

- support for research data, including large and complex data types

- gold Open Access which fosters wider collaboration and increased citations

- maximum visibility for your research: over $100 \mathrm{M}$ website views per year

At BMC, research is always in progress.

Learn more biomedcentral.com/submissions 